\title{
Modern Trends in Farm Machinery-Electric Drives: A Review
}

\author{
Dipak S. Khatawkar ${ }^{1 *}$, P. Shaji James ${ }^{1}$ and D. Dhalin ${ }^{2}$ \\ ${ }^{1}$ Department of Farm Machinery and Power Engineering, Kelappaji College of Agricultural \\ Engineering and Technology, Tavanur, India \\ ${ }^{2}$ Department of Agricultural Engineering, College of Agriculture, Vellayani, India \\ *Corresponding author
}

\begin{tabular}{|l|}
\hline Ke y w or d s \\
$\begin{array}{l}\text { Tractor, Electric } \\
\text { drive, ISOBUS, } \\
\text { Powertrain }\end{array}$ \\
\hline Article Info \\
\hline $\begin{array}{l}\text { Accepted: } \\
\text { 04 December } 2018 \\
\text { Available Online: } \\
\text { 10 January 2019 }\end{array}$ \\
\hline \hline
\end{tabular}

A B S T R A C T

The most mechanized agricultural operations include a tractor as a primary power unit, even though the tractor itself is not particularly useful without an implement attached. Innovations and efficiency improvements in tractor engines, powertrains, and auxiliary power systems have been ongoing since tractors were invented a century ago and significant gains have been realized. However, PTO and hydraulic power systems are well established and effective for today's applications, the search for more versatile and efficient power transfer continues. One alternative is electric power, which first debuted in 1954 on the Farmall Electrall tractor (Michael, 2012). The recent research suggests electric drives would be suitable and beneficial for almost all the drives on modern agricultural machines, which currently use hydraulic and mechanical power. Electric drive enables variable speeds control; therefore, functions can be operated independently of engine speed and use only the power and energy needed for the given function. ISOBUS, a communication protocol for high voltage power electronics controller networks on agricultural machinery, is a key enabler for advanced controls that take advantage of torque and speed control capabilities of these electric systems. Electric powertrain promises the higher fuel efficiency and better torque-speed control over the mechanical and hydraulic one. Hence, it is inescapable to switch over to electric powertrain so as to meet the forthcoming requirements of sustainable precision agriculture and to reduce the global emission.

\section{Introduction}

Today, the modern agriculture farm includes a tractor as a key power unit. Considerable efforts have been focused on tractors, since it's the point where the fuel is being consumed (Moreda et al., 2016). The explanations for the general improvement in the PTO and drawbar specific fuel consumption are documented rarely. However, the influences include advancements in IC engine construction and transmission, fuel delivery mechanism and turbocharger technology.

At present, most of the agricultural tractors deliver power through drawbar, rear PTO shaft and hydraulic lift system. The current investigations recommend that electric drives 
could be apt and advantageous most of the drive mechanisms on present agricultural machineries (Karner et al., 2012). The first electric power alternative was debuted in 1954 on the Farmall Electrall tractor. The Farmall 450 was equipped with combined electric power generator having $10 \mathrm{~kW}$ of output power rating. Due to restricted electrical controls, the technology failed to capture the market adoption at that phase (Michael, 2012; Stoss et al., 2013).

Electric drives permit flexible speed control and it can be functioned individually to consume the power required for the particular operation alone. Tractor ancillaries such as radiator fan, air compressor motor, water and hydraulic oil pumps can be driven electrically (Bunning, 2010; Marlin, 2011).

Electric powertrain promises the higher fuel efficiency and better torque-speed control over the mechanical and hydraulic one. Hence, it is advantageous to switch over to electric powertrain so as to meet the global requirements of emission norms and adaptability to precision agriculture.

\section{Tractor electrification}

\section{Validation of electric hybridization of tractor}

The Society of Automotive Engineers (SAE) has precisely specified the definition of "hybrid vehicle" as a vehicle with two or more energy systems both of which must provide the propulsive power either together or independently. SAE also defines Hybrid Electric Vehicle (HEV) as a vehicle that can utilize the propulsive power from both of the energy sources i.e. fossil fuel as well as rechargeable electricity storage system (Moreda et al., 2016). In 2009, Nemry et al., proposed the terminology "electric drive vehicle" (EDV) meant for the automotive system in which power is delivered to the traction wheels through an electric motor. The electric motor used in EDVs could be powered either exclusively by a RESS or coupled with an internal combustion engine (ICE). The EDV would involve five categories of vehicle i.e. battery electric vehicles (BEVs), HEVs, plug-in hybrid electric vehicles (PHEVs) and fuel cell vehicles (FCV).

Rydberg (2009) stated that in many cases the electric motors may lag compared to hydraulic motors in terms of Power to Weight Ratio (P/W). Even though, as per information given in Table 1 synchronous permanent magnet motor (92\%) outpaces to hydraulic motor $(71 \%)$ in case of efficiency. The major advantage due to which electric drive leaves behind the hydraulic drive is nothing but the ease of integration with control electronics.

Boldea et al., (2014) studied the sophisticated combination of internal combustion engine with an electric drivetrain which may result into improved energy efficacy, i.e. reduced fossil fuel ingestion which ultimately shoots down the $\mathrm{CO}_{2}$ emission. The level of integration of power electronics and electric drives within the conventional powertrain specify the hybridization grade.

The hybridization grade or factor (HF) of an automobile is referred as the ratio of electric drive power to the total drive power i.e. sum of electric and engine power.

$\mathrm{HF}=\mathrm{P}_{\text {Electric }} /\left(\mathrm{P}_{\text {Electric }}+\mathrm{P}_{\mathrm{ICE}}\right) \ldots(\mathrm{i})$

Where, $\mathrm{P}_{\text {Electric }}$ is the power output of electric drive and $\mathrm{P}_{\text {ICE }}$ is the power output of IC engine.

Chan (2007) projected conversing to the factor of hybridization, HEV could be categorized into micro-hybrids $(0<$ HFactor $<0.1)$, mildhybrids $(0.1<$ HFactor $<0.25)$, full-hybrid 
(0.25<HFactor< 0.5) and Plug-in-HEVs $(0.5$ $<\mathrm{HF}<0.7)$. The value of $\mathrm{H}$ Factor $=1$, if the vehicle has 'pure' electric drivetrain similar to the BEVs.

Soma et al., (2015) recommended a specific factor of hybridization for the vehicles with hydraulic actuators, which require propulsive power as well as hydraulic power. The hydraulic pump can be driven exclusively by the IC engine or by means of electric motor drive. Focusing on the later circumstance, they suggested a specific factor of hybridization for stacking or piling (SHF2) ensuing equation (i) and the specific factor of hybridization for propulsion (SHF1). Hypothecating the time dispersal dedicated to propulsive and stacking work, the overall factor of hybridization (OHF)for the vehicle system can be calculated as the algebraic mean of SHF1 and SHF2.

\section{Energy generation for engine ancillaries and electrified equipment}

The key novelty in hybridising a vehicle is to produce electrical power for IC engine auxiliaries. The main purpose is to take away the conventionally driven non-propulsive loads (radiator fan, water pump rotor and air compressor etc.) off the engine. Removal of such loads, shrink the dependent losses resulting improvement in overall vehicle efficiency. Moreover novel functionalities arise, such as an electrically operated radiator fan, which could be turned reversely with a dipolar switch to blow the dust deposited within the radiator panel grid. It may seem like converting the mechanical loads to electric one is ineffectual, due to the parallel losses accompanied in generating the corresponding electrical power and consecutive ultimate translation to mechanical drive energy. However, these losses are remunerated by the virtue of being electrical component; such loads could be turned on or off, or moreover superiorly influenced as per the real time need.

Mitchell et al., (2009) compared the modified engine cooling system featuring speed regulated electric radiator fan and water impeller against the normal engine cooling systems. They found the electrified cooling system outperformed the conventional one on the basis of engine warming spell, temperature monitoring and power expenditure.

Mohseni Manesh (2014) explored the functionality of John Deere E-Premium tractor series (E7430/E7530) introducing three phase $(480 \mathrm{~V}, 20 \mathrm{~kW})$ induction generator coupled with diesel engine (132 kW) flywheel. Electric power generated is partially utilized to operate two engine accessories; these speed adjustable non-propulsive loads are the radiator cooling fan and air compressor motor. Also, these tractors featured with two parallel power outputs at the tail side, in which one provided single phase (1 230V AC) and other one with three phase (3 400V AC). The power outputs could be employed to energize a number of electrically driven tools and machines, such as the irrigation pump, arc welding machine or electric chain saw etc.

Pessina and Facchinetti (2009) conducted comparative study on fuel consumption of7530 E-Premium and its conventional equivalent in two operating circumstances as harrow operation and trailer road transport. The E-Premium showed reduced fuel expenditure of 4 per cent over its equivalent rival variant in the harrow operation, whereas this difference rose to 16 per cent towards hybrid variant in the case of trailer transportation.

The last decade has spent more attention towards turbocharging and turbo-electrocompounding technology (Singh et al., 2014), as the key to enhance overall energy efficiency of the vehicle. Turbo-electrocompounding comprises of extracting the 
energy from ICE exhaust gases. After departing through the turbo-impeller, they turn a secondary turbine to drive a dynamo (Fig. 1).

\section{Electric power interface}

ISOBUS is a communication protocol for high voltage power electronics and controller based sensor network on agricultural machines. It is a major support system for advanced electronic control technology which gains benefit of torque-speed regulation technique (AEF-ISOBUS guidelines, 2015).

\section{Traction drives}

Emadi et al., (2008) suggested that HEVs and PHEVs powertrain systems could be of two categories: parallel type and series type (Fig. 2 \& 3). Parallel driveline consists of a mechanism in which, mechanical as well as electrical power source are capable of driving the transmission system, either in combination or discretely.

The driveline comprise of an electric device, which can be deployed as generator or motor $(\mathrm{M} \approx \mathrm{G})$. The shortcoming of the parallel style is being impotent to charge the storage battery when the $\mathrm{M} \approx \mathrm{G}$ is powering the transmission.

The farm tractor, which not only mandates to thrust itself but also has to deliver power to the attachments, a committed electric generator is the key requirement. Therefore, the parallel powertrain design would not be the most suitable for an agricultural tractor. However, the first shortcoming recognized in the series manner is the conventional engine, the electric generator and drive motor are designed to create the complete power of the vehicle.

Consequently, the gross weight, initial cost and space requirement of the system may become excessively high.
Nevertheless, series architecture takes some key benefits. Mainly, due to absence of any mechanical connection among the main engine and the drive mechanism, the engine and electric generator set could be placed over chassis, wherever desired.

Hofman et al., (2009) suggested the introduction of a continuously variable transmission (CVT) could be conceivable. Shabbir and Evangelou (2014) stated, as the conventional mechanical components like transmission rods or shafts are not essential; the in-wheel AC/DC motor drive can be adopted with no trouble (Fig. 3).

By virtue of individually operable four drive wheels, better tolerance can be endorsed concerning the dissimilar tire radii, ensuing reduction in tyre wear. For example, the Rigitrac EWD120 is a diesel-electric tractor highlighting four $33 \mathrm{~kW}$ in-wheel motor drives along with an electric generator of 85 kW power output (Herlitzius, 2011). Whereas, the series mechanism featuring single electric motor mated to the mechanical gearbox was employed in Belarus 3023.

The comparative test results among Belarus 3023 diesel-electric tractor and its conventional variant were reported by Florentsev et al., (2011) and Puhovoy (2011). Both variants were provided with identical tyre configuration and employed to till to similar soil depth with the exact same plough.

The specific fuel consumption for the hybrid variant with was found $10.8 \mathrm{~kg}$-ha ${ }^{-1}$ against $13.2 \mathrm{~kg}-\mathrm{ha}^{-1}$ in case of conventional variant. Therefore the ratio of shift of $2.4 \mathrm{~kg}-\mathrm{ha}^{-1}$ between the corresponding SFCs which and $13.2 \mathrm{~kg}-\mathrm{ha}^{-1}$ profited the fuel economy of 18 per cent towards the hybrid variant. Moreover, the hybrid variant was introduced with speed controlled motor driven front PTO which offers a novel functional feature. 


\section{Fuel cell powered electric tractor}

In1960, Allis-Chalmers - US based industrial machinery manufacturer developed the first fuel cell tractor (Barucki, 2001). New Holland in 2009, revealed their fuel cell powered $\mathrm{NH} 2^{\mathrm{TM}}$ e-tractor (Fuel Cells Bulletin, 2009). Later in the year 2011, they released next form of fuel cell powered e-tractor. The later version was provided with $100 \mathrm{~kW}$ rated power fuel cell as compared to the first version with rated fuel cell power of $50 \mathrm{~kW}$ (Fuel Cells Bulletin, 2012). The later version was provided with two electric motors (100 $\mathrm{kW}$ rated power each motor): first for propulsion and second to drive PTO and hydraulic pump. The hydrogen tank capacity was designed to store $8.2 \mathrm{~kg}$ of $\mathrm{H}_{2}$ at a pressure of $350 \mathrm{bar}$, while $300 \mathrm{~V}-12 \mathrm{~kW} \mathrm{~h} \mathrm{Li}$ ion storage battery was provided to facilitate plug-in charge.

Tritschler et al., (2010) explored the prospects of a FC hybrid powertrain in farm tractors. Table 2 comprises a contrast between various the hybrid farm tractors abovementioned.

Gallmeier and Auernhammer (2004) studied the overall vehicle efficiency of certain powertrain mechanisms on the basis of corresponding major power sources. The tank to wheel efficiency was found 50 per cent for the fuel cell as a power source, which was higher as compared to the diesel engine power source with 32 per cent overall efficiency.

\section{Energy recovery and storage}

Scientifically, a vehicle should deteriorate only the amount of energy required to overcome friction. Osinenko et al., (2007) suggested that the energy expended in acceleration and hill climbing could be recuperated while braking and descending respectively. For any vehicle, the external friction takes place against air and the rolling resistance over a particular terrain. In comparison to the terrain vehicles, in addition to the internal rolling resistance owing to tyre distortion, farm tractors are in exposure to the external rolling resistance caused by deformation of soil in contact. The CVT based fully hybrid drives have already been recognized for their capability to encompass greater fuel economy than that of conventional powertrains in urban scenario (Rossi et al., 2014).

On the basis of Faraday-Lenz law, HEVs recuperate energy by the virtue of regenerative braking. The technology depends on the reversible nature of electrical rotary devices. The device acts as a motor when supplied external electrical energy, creating mechanical twisting force i.e. positive torque. On the other hand, it offers negative - braking - torque, since it is generating electricity and acts as a generator.

Katrasnik (2007) recommended that the energy can be recovered when the electrical rotary device functioning as an electricity generator to charge the storage battery. This can be achieved by either incorporating regenerative braking or gripping the excess engine power. Hoy et al., (2014) explored the probability of coupling GPS data to the active powertrain controller. In accordance with the energy recuperation and its storage, topographic information can be allowed to expend energy through the battery little in advance of uphill commencement, in the view of recharging the battery via downhill regenerative braking. Besides storage batteries, the ultracapacitors or supercapacitors could also be used for onboard energy storage (Fig. 4). Contrary to electrochemical storage battery, a supercapacitor provides low energy density and high power density. Among electrochemical storage devices, lead accumulator (Pb-acid), Nickel metal hydride 
(Ni-MH), and Lithium ion (Li-ion) batteries are the dominant and reliable technologies at present. Mousazadeh et al., (2010) studied various electricity storage techniques pertaining to corresponding specific energy, energy conversion efficiency, self-discharge period, charge-discharge phases, and cost analysis. The analysis showed the Li-ion to be the unsurpassed storage technology so far, superior to the other technologies in complete manner - excluding the charging up time, where the lead accumulator battery evidenced better. Recent research has explored the potential of electrochemical characteristics of grapheme, which is growing as a key area of investigation.

Kucinskis et al., (2013) emphasized on the ability of graphene to improve the electron conductivity of electrode constituents in storage batteries. Kim et al., (2014) anticipated the all-graphene battery as a cutting-edge energy storage technology, constructed using graphene as both anode and cathode.

\section{Implement and self-propelled harvester electrification}

The high voltage electricity supply can be provided to link the electrically workable equipment, by featuring the tractor with a high voltage generator coupled directly to the engine. The electric power interfaces can be positioned at front and/or rear side of the tractor. Second way is that the implement should be having its specific generator mounted on it, which can be coupled to the tractor PTO. Also a portable genset can be mounted at the front of the tractor. Since it creates the anterior hitch unapproachable in attaching front mount implement, becomes troublesome alternative. Karner et al., (2012) considered the agricultural machinery manufacturers in Austria, about their concern in electrified agricultural machines. Almost
$1 / 3^{\text {rd }}$ among them were in the view of developing an electrified machine versions in upcoming short period, next $1 / 3^{\text {rd }}$ would continue expectant to other competitor's actions, and the remainder did not disclose their opinion regarding the subject. From the first $1 / 3^{\text {rd }}$ manufacturers, 47 per cent were focussing to electric drives due to efficacy reasons, whereas the leftover 53 per cent were engaged for the improved functionality intentions.

\section{Planters}

The Kinze Inc, a planter maker introduced an electric version in its planter 4900 succession. The distinctive feature of the electric driveline is capable of maintaining steady seed spacing through the inner row to the outer while working on curved rows. Furthermore, the excessive noise related to mechanical parts such as drive shafts, chains-sprockets and gears etc. is eliminated. Götz et al., (2012)and Rahe et al., (2013) conducted field trials on electrified tractors. The research plan was focussed on the major goals of operating engine auxiliaries electrically and supplying power for an electrified implement, through a $50 \mathrm{~kW}$ PMS generator driven by164 kW primary diesel engine. The engine cooling fan was driven by a $15 \mathrm{~kW}$ electric motor. The Amazone make EDX eSeed pneumatic planter fitted with dual $3 \sim 400 \mathrm{~V}-11 \mathrm{~kW}$ motors, was selected as an electrified test implement. These two motors were employed to drive the fertilizer and seed delivery system. The results analyses showed $30 \%$ lower energy consumption as compared to the conventional (hydraulic motor driven fan)variant.

\section{Sprayers}

The energy wastage can be reduced considerably by introducing smart-electric drive mechanisms in chemical applications via precise electronic controller system. For 
instance, in the electric version of the Amazone make Spray trailed sprayer, the sprayer is driven without any mechanical power transmission.

The separation of sprayer drive from primary engine permits for the specific individual control within the spray mechanism. Thus, the spray chemical delivery and the fresh water path could be controlled separately, which enables the farmer to step into variable rate application technique (Amazone, 2009).

A four wheel drive diesel electric hybrid sprayer developed by AGCO Ltd. was introduced with electric in-wheel motors, having rated output power of $84 \mathrm{~kW}$ each (Neunaber, 2011). The liquid cooled electric generator capable of producing either $200 \mathrm{~kW}$ at $1500 \mathrm{rpm}$, or $240 \mathrm{~kW}$ at $1900 \mathrm{rpm}$. The generator output (650 V DC) was inverted to 3 phase $\mathrm{AC}$, to power the in-wheel motor drives.

The electrical circuitry was featured with a power resistor to shut down the whole circuit voltage to zero, within just $4 \mathrm{~s}$ after ignition switch-off. Earlier in 2010, the manufacturer AGCO Ltd., demonstrated the performance evaluation of the electric version with its conventional variant in USA.

The two variants were operated at $19 \mathrm{~km}-\mathrm{h}^{-1}$ and $29 \mathrm{~km}-\mathrm{h}^{-1}$ on fairly flat fields and on gradients up to $10 \%$. Both variants covered an area of 36 ha individually for four times.

During the initial summer period of 2010, the diesel electric version expended 20 to 30 per cent lesser fuel as compared to the conventional variant. However, during fall fuel consumption was observed to be around 25 to 30 per cent lesser in case of diesel electric version. Despite aforementioned advantages, the diesel electric variant brought extra dead weight $800 \mathrm{~kg}$ higher than its conventional equivalent.

\section{Fertilizer spreaders}

Rauch (2010) investigated the performance of different fertilizer dispersal disc mechanisms viz. mechanical, hydraulic and electric type. The electric version comprised of dual 3 phase $480 \mathrm{~V}-13 \mathrm{~kW}$ motors, at $5000 \mathrm{rpm}$ spinning rate. He concluded that electric drive equaled efficiency of mechanical drive at maximum disc torque, whereas its ur passed efficiency of mechanical and the hydraulic drive at any lower value of disc torque. Another advantage of electric drives is rotary discs could be stopped more swiftly, by virtue of electrical braking.

\section{Harvesters and threshers}

Bernhard and Schlotter (2003) hypothesized that if a combine harvester was electrified, then the machine weight and initial cost will increase. On the optimistic side the electric drivelines could be controlled discretely with precision, resulting better fuel economy. Scheidler et al., (2009) investigated the advantages of electrically driven combine harvester's grain delivery auger. It might be conceivable that the motor shaft could be rocked in either direction momentarily to induce the grain movement. Also, the active response from power interface could be accounted as a pointer of grain discharge rate to regulate the auger motion as per required. Bernhard and Schreiber (2005) claimed that in terms of average $\mathrm{P} / \mathrm{W}$ value of electric drivelines, the weight of the electric drive components is around six fold more than that of the hydraulic one. However, by considering the gross weight of the combine harvester, this added weight denotes only 3 per cent.

Bernhard and Kutzbach (2002) mounted an electronically managed hydrostatic CVT series driveline and electric CVT series driveline in the similar combine harvester. The study was aimed to perform the field tests for analysing 
performance quality among the two mechanisms. The hydrostatic driveline was consisted of a variable rate displacement hydraulic pump and a variable rate displacement hydraulic motor. Whereas, the electric driveline comprised of PMS type generator and a three phase induction motor. Aumer et al., (2008) projected overall efficiency of 72 to 80 per cent in case of electric drive system and 40 to 68 per cent for the hydrostatic drive system. Gallmeier (2009) established a hybrid electric drive mechanism for operating the header and intake onto a selfpropelled forage harvester. The overall efficiency of 23.3 per cent higher than the conventional hydraulic drive was recorded for the developed electric drive system.

Favache (2002) developed a thresh roller with internal motor drive mechanism. Due to this arrangement, the intake capacity of the thresher was optimised for a particular width, as the adjacent space needed for conventional mechanism is saved. The application of electric powertrains can significantly reduce the machine complexity by 60 per cent, in terms of total of transmission components.

\section{Straw-balers}

Kupfer and Leu (2013) discussed about the defect of film ripping in the enfolding part of a round type baler. Their study revealed that the physical characteristics of the film material vary with the change in working temperature. Thus to overcome the film slitting, an appropriate torque with respect to the operating temperature must be applied while wrapping. As discussed earlier, the electric drives can be controlled with better precision as compared to the hydraulic one. The electronic sensor based network controller can be employed to monitor and modify the operating torque or halt the operation in less than half second to restrict the film slitting. Biziorek (2012) developed a round type baler featuring a roller with an internal electric motor drive mechanism. Both shaft speed and direction of rotation were electronically governable. The full control over roller motion enabled the operator to eradicate the risk of choking and unwinding of wrap while unloading. Additional benefit of the electric drive is that the roller could be run slowly in the starting stage after expulsion of the preceding bale.

\section{Impending applications and future developments}

Electrification of on-road and off-road vehicles including civil as well as agricultural machinery has got prime importance in present research and development around the globe. Ponomarev et al., (2015) suggested that to be in competition, manufactures must deliver energy proficient hybrid variants to the consumers. Apart from the urban vehicles, application of electric drivelines in farm tractors would open up with novel possibilities, as the farm machineries are involved with an enormous diversity of functional drivelines (Karner et al., 2013). Pohlandt and Geimer (2015) put forward certain merits and limitations of electric and hydraulic drivetrains (Fig. 5). The concept of energy recovery has been adopted with relative ease in case of urban vehicles, owing to recurrent hastening and brakes. Similarly, in case of construction machinery which involves frequent actions, are being capable of recovering kinetic energy. In the field off arm machinery, the two major areas have been recognized so far (Barthel et al., 2014) in which a significant energy retrieval is conceivable, one is trailer transportation and bucket elevator job (Soma, 2013 and Soma et al., 2015).

Ebbesen et al., (2013) discussed various difficulties in the process of optimizing the capacity of electric drive motor, primary 
engine and energy storage device. The optimized design should offer maximum fuel economy for desired performance reasonable cost. The major influencing components for an effective design of electric vehicle are the motor type, electronic power management system and energy storage device.

At present, the PMS type motors are dominant, while alternate kinds of motors are under research and development for implementing in electric vehicles. However, the resource and cost of rare-earth permanent magnetic material is a major constraint, exploration is being focussed on development of the electric motors, such require none or very little amount of such substance (Dorell, 2012). The global leading manufacturer Tesla Inc. is using induction motors in their EVs, whereas Land Rover Inc. is practicing switched reluctance motor in its Defender 110 electric sports utility vehicle (ESUV).

According to Ehsani et al., (2007) discussed over an adverse acoustic noise related to the switched reluctance type motor. The varieties of electric motors that apparently may take the major contribution in the upcoming years due to their precise controllability and less maintenance are illustrated in Figure 6.

Table.1 Efficiency and P/W ratio comparison of electric and hydraulic motors

\begin{tabular}{|c|l|c|c|c|c|}
\hline $\begin{array}{c}\text { Sl. } \\
\text { No. }\end{array}$ & \multicolumn{1}{|c|}{ Classification } & $\begin{array}{c}\text { Conversion } \\
\text { efficiency }\end{array}$ & $\begin{array}{c}\text { Power Output } \\
\boldsymbol{P}, \mathbf{i n ~} \mathbf{~ W}\end{array}$ & $\begin{array}{c}\text { Mass } \\
\mathbf{W} \text { in } \mathbf{~ k g}\end{array}$ & $\begin{array}{c}\boldsymbol{P} / \boldsymbol{W} \\
\text { in } \mathbf{~ k W . k g}\end{array}$ \\
\hline $\mathbf{1 .}$ & $\begin{array}{l}\text { Permanent magnet } \\
\text { synchronous type }\end{array}$ & $92.0 \%$ & 12.00 & 49.00 & 0.240 \\
\hline 2. & Cage rotor induction type & $90.2 \%$ & 11.00 & 97.00 & 0.110 \\
\hline 3. & $\begin{array}{l}\text { Synchronous reluctance } \\
\text { type }\end{array}$ & $93.3 \%$ & 11.00 & 69.00 & 0.160 \\
\hline 4. & $\begin{array}{l}\text { Hydraulic motor orbital } \\
\text { type }\end{array}$ & $71.0 \%$ & 11.00 & 5.90 & 1.860 \\
\hline $\mathbf{5 .}$ & $\begin{array}{l}\text { Hydraulic motor radial } \\
\text { type }\end{array}$ & $89.0 \%$ & 12.00 & 40.00 & 0.300 \\
\hline
\end{tabular}

(Source: Rydberg, 2009)

Table.2 Architectural comparison of electric hybrid tractors

\begin{tabular}{|c|c|c|c|c|}
\hline $\begin{array}{l}\text { Sl. } \\
\text { No. }\end{array}$ & Tractor & $\begin{array}{l}\text { Major } \\
\text { power } \\
\text { source }\end{array}$ & Storage battery & Drivetrain mechanism \\
\hline 1. & Belarus 3023 & $\begin{array}{l}\text { Diesel } \\
\text { Engine }\end{array}$ & No & $\begin{array}{l}\text { Series CVT with single } \\
\text { propulsion motor }\end{array}$ \\
\hline 2. & $\begin{array}{l}\text { John Deere } \\
7430 \text { E-Premium }\end{array}$ & $\begin{array}{l}\text { Diesel } \\
\text { Engine }\end{array}$ & No & Conventional \\
\hline 3. & $\begin{array}{l}\text { Rigitrac EWD-120 } \\
\text { Diesel Electric }\end{array}$ & $\begin{array}{l}\text { Diesel } \\
\text { Engine }\end{array}$ & No & $\begin{array}{l}\text { Series CVT with individual in } \\
\text { wheel electric drive per wheel }\end{array}$ \\
\hline 4. & $\begin{array}{l}\text { New Holland } \\
\mathrm{NH} 2^{\mathrm{TM}}\end{array}$ & $\begin{array}{l}\text { Hydrogen } \\
\text { FC }\end{array}$ & $\begin{array}{c}\text { Yes } \\
300 \mathrm{~V} \text { Lithium ion }\end{array}$ & CVT with one traction motor \\
\hline
\end{tabular}

(Source :Tritschler et al., 2010) 
Fig.1 Schematics of Turbo-electro-compounding technique

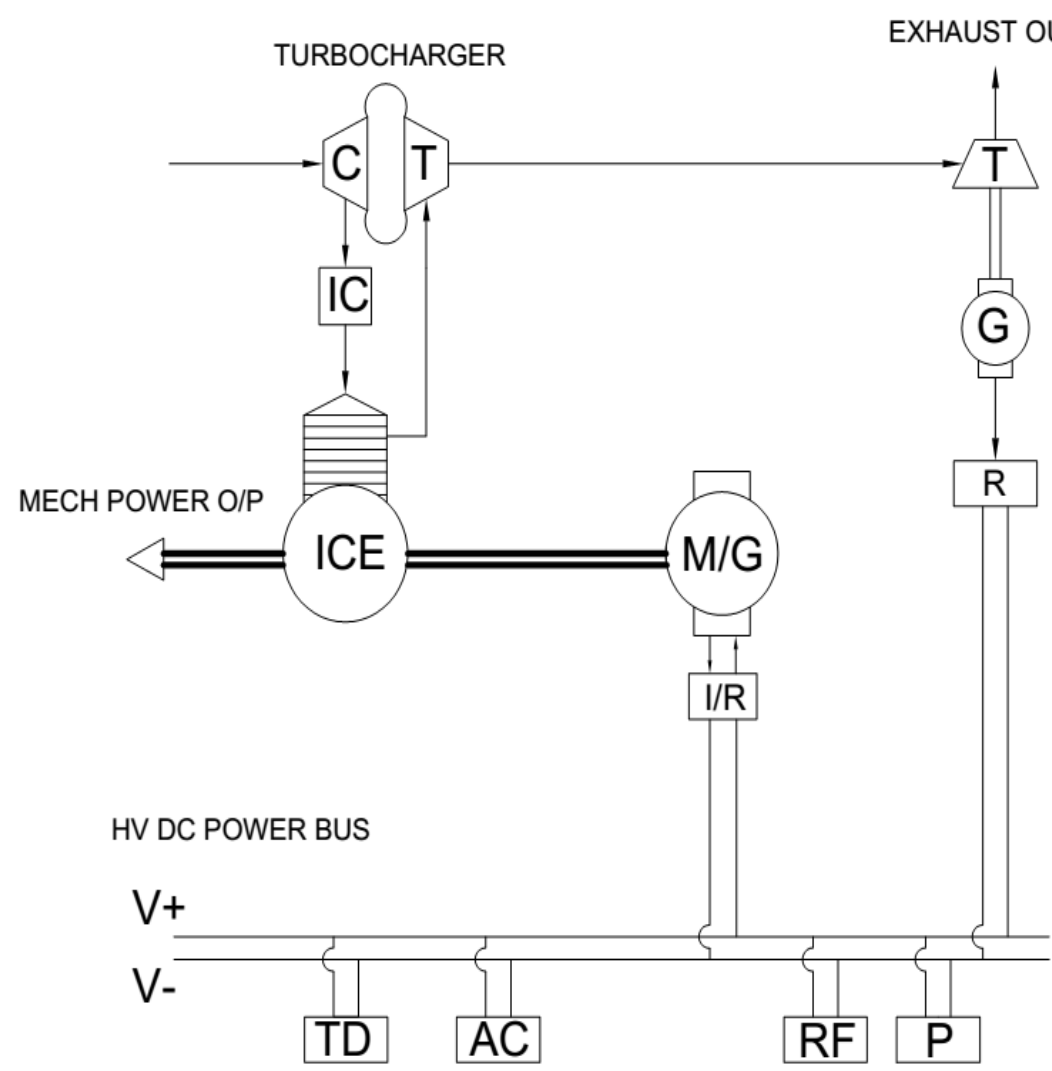

\begin{tabular}{|c|c|}
\hline \multicolumn{2}{|c|}{ KEY } \\
\hline$C$ & COMPRESSOR \\
\hline$T$ & TURBINE \\
\hline IC & INTERCOOLER \\
\hline ICE & $\begin{array}{c}\text { INTERNAL COMBUSTION } \\
\text { ENGINE }\end{array}$ \\
\hline M/G & MOTOR/GENERATOR \\
\hline I/R & INVERTER/RECTIFIER \\
\hline G & GENERATOR \\
\hline$R$ & RECTIFIER \\
\hline TD & TRACTION DRIVE \\
\hline AC & AIR CODITIONING \\
\hline RF & RADIATOR FAN \\
\hline$P$ & PUMP \\
\hline
\end{tabular}

Fig.2 Series style CVT with single traction motor

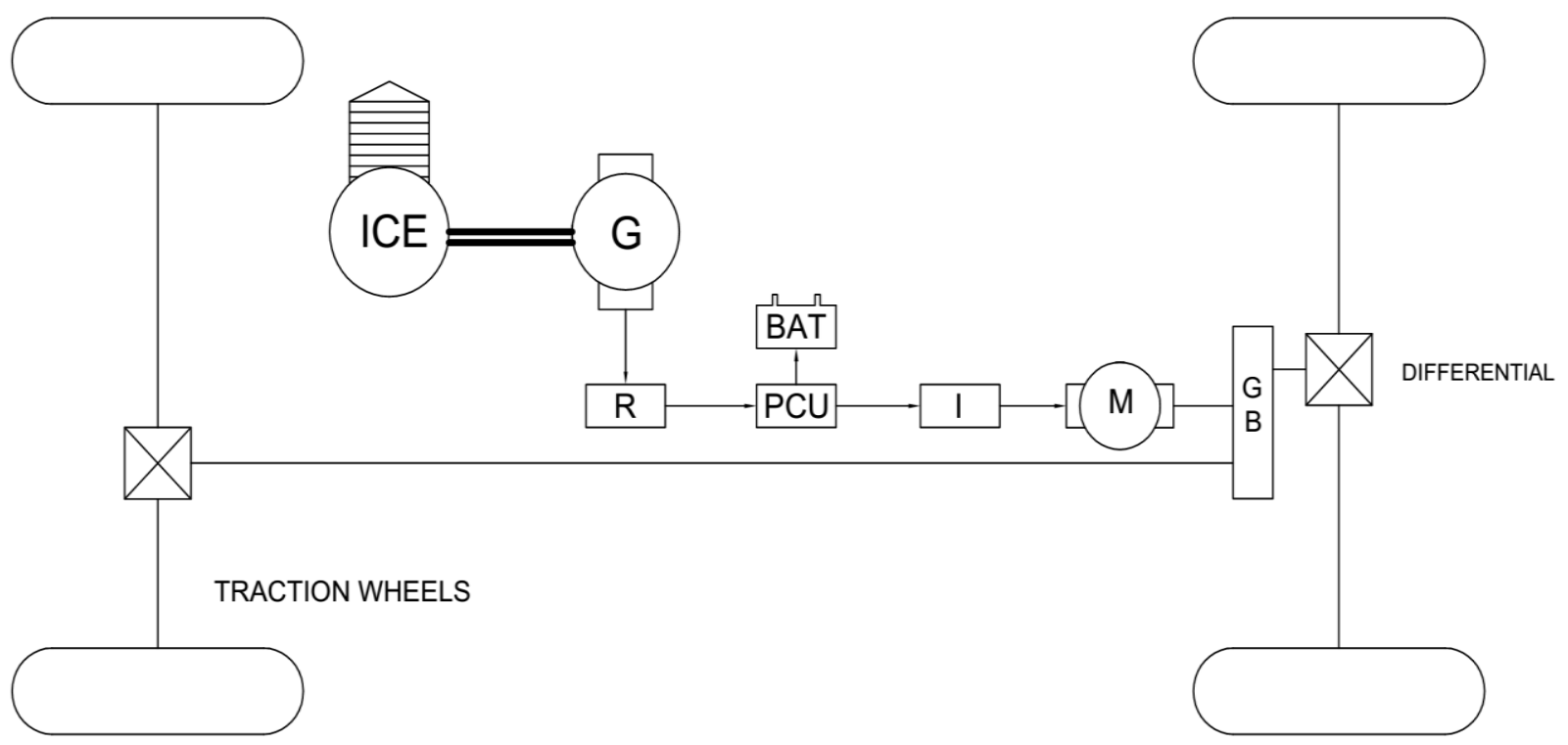


Fig.3 Series style CVT with individual motor per traction wheel

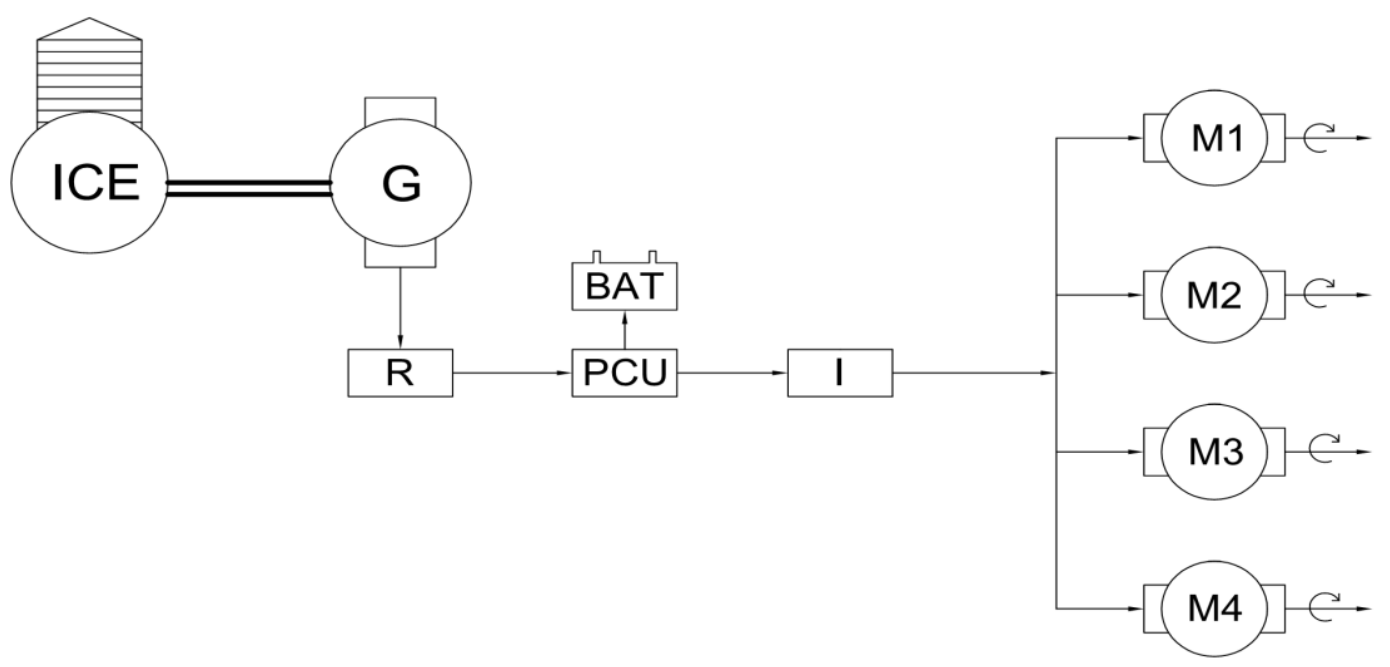

Fig.4 Technologies for energy storage

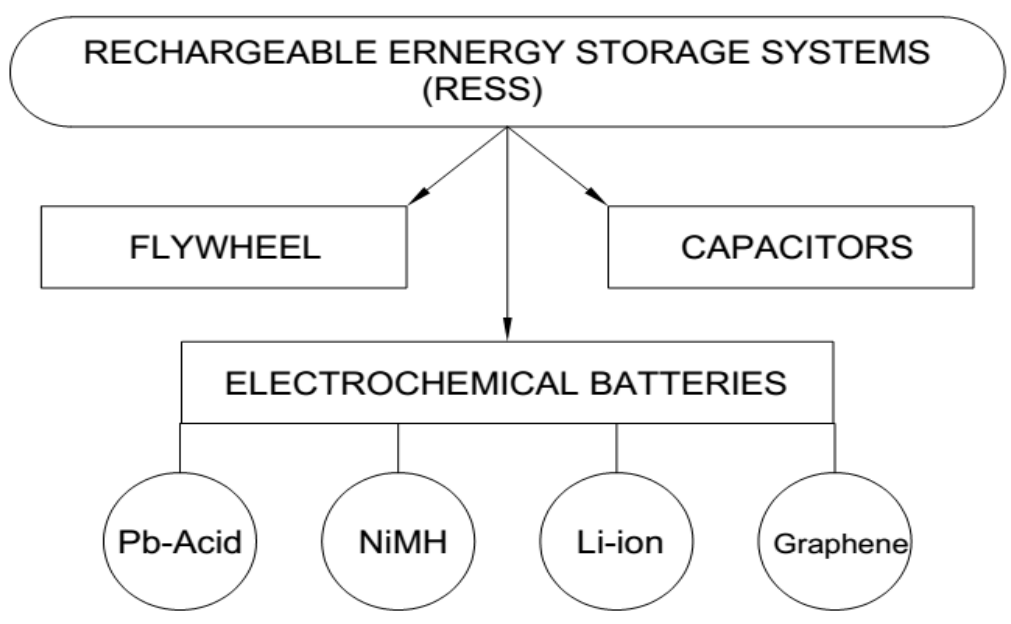

Fig.5 Hydraulic powertrain (HPT) Vs. Electric powertrain (EPT)

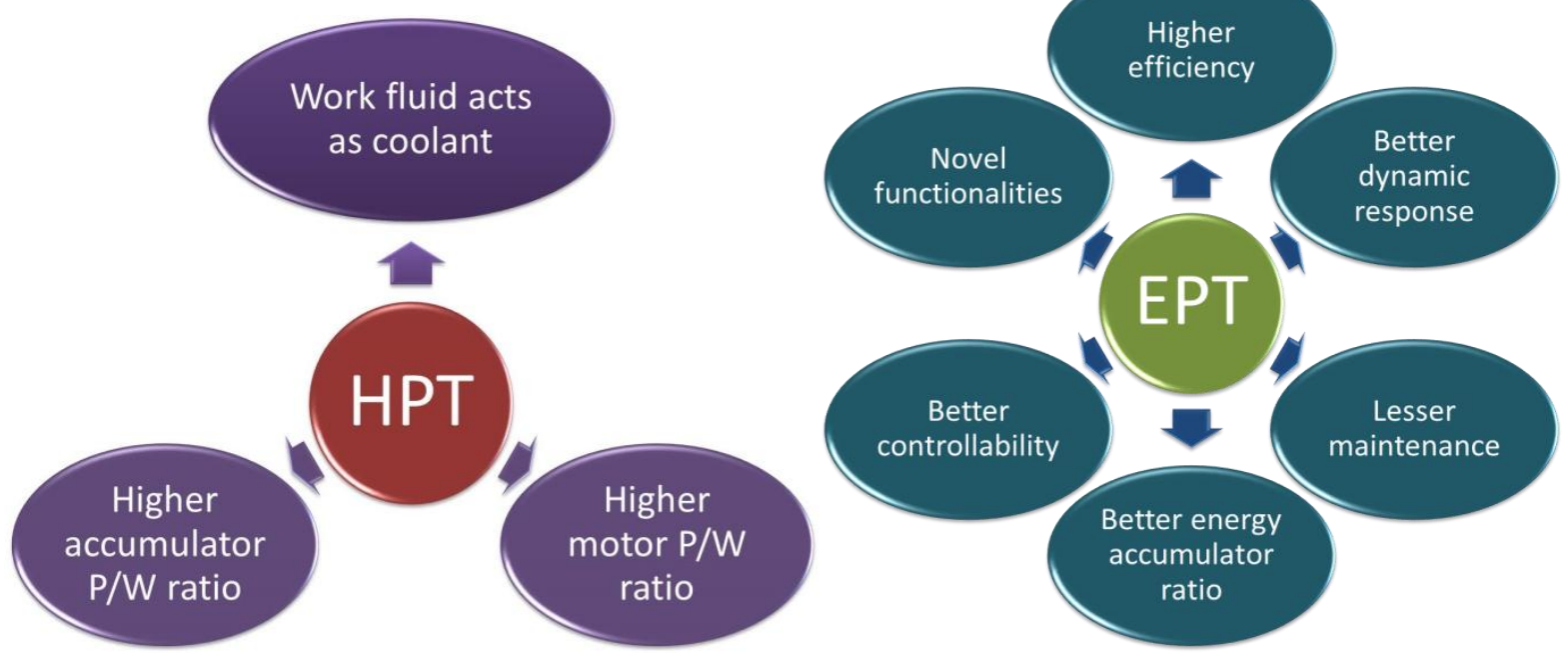


Fig.6 Electric motors for electrification of tractors and agricultural machinery

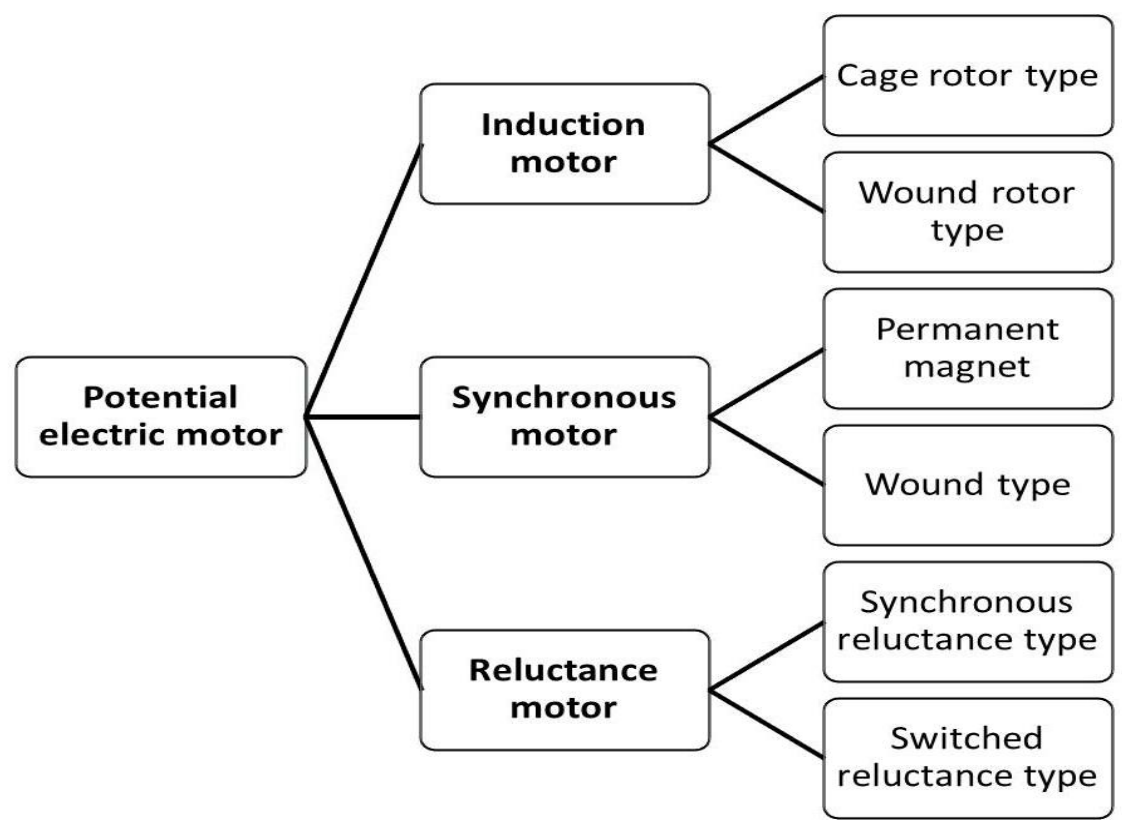

Angrisani et al., (2015) identified that plug-in type hybrid can be charged through the external electric power sources like AC mains charging points or farm yard garage and it is more effective as compared to the HEVs to decrease fossil fuel consumption. The plug-in charge feature open up the use of various higher energy conversion efficient technique as well as the renewable energy sources. Usually, the smartest approach to achieve the better energy dissemination among the storage battery and the primary engine in PHEV is to utilize electric power to run the transmission, till the battery potential falls to a pre-set low-threshold, normally 30 per cent of the full charge potential (Chen et al., 2014). The plug-in type EVs are typically featured with an on-board charging circuit and recharging the storage batteries from the AC mains network is the simplest way. It is evident that battery recharging from the AC mains is highly efficient way than charging through vehicle primary engine. It appears logically better to hybridize the tractor with a high power battery and thrust motor which could be combined with smaller primary engine. The battery unit could be put on charge through night in farm machinery yard and would be utilized during field operation on subsequent day time. The smaller engine could be turned on to keep the battery potential above low threshold on the go. United Nations Economic Commission for Europe (UNECE Reg. No.100 Rev-2, 2013) established the key protection criteria governing the electric drivetrain of on-road automobiles. In a conventional IC engine powered vehicle using a $12 \mathrm{~V}$ DC electric circuitry, the major threat is short-circuit between the two electric poles. In addition to this, a high voltage electrical system comes up with a different death-trap, i.e. electrical shock. Contrasting to the conventional electrical wiring practice, both positive and negative high voltage lines are isolated from the vehicle metal framework. Furthermore, continuous monitoring for high voltage leakage to the vehicle frame work is being performed through a digital ground fault detector system (AGCO, 2014).

In conclusion, from the reviewed research and development in the area of high voltage electrification of agricultural tractor and 
related equipment, the following conclusions can be drawn:

The electric powertrains permit more flexible design than mechanical and hydraulic drives. Also, introduction of a dedicated high power battery source augments a second degree of freedom for the vehicle propulsion.

The present literature reports higher overall energy conversion efficiency of electric drivelines over hydraulic and mechanical drivelines.

Agricultural tractor and other related machinery have the huge opportunity of pursuing the trails of hybridized urban vehicles to encompass the energy recovery.

There is a massive scope for more detailed analyses to discover the potential operations in which energy retrieval is conceivable among the agricultural machinery.

The concept of charging high voltage batteries from the farm machinery yard mains at night and working on electric power during field operations, while utilizing downsized ICE for trickle charge of batteries on the go shows better practice.

There is an urgent need of conducting investigations on cost of owning, operating and maintenance of the agricultural machinery to compare various conventional vs. electrified tractorimplement combinations.

The electrification of agricultural machinery promises the tremendous reduction in emissions and thereby restricting further environmental pollution, other than higher overall efficiency and economic benefits.
Future of electric hybridization of farm machinery

As per the forthcoming stringent emission control norms through international organizations and government regulations, it is clear, the time to switch over to less or nonpolluting and more efficient hybrid-electric powertrains in agriculture sector is near and inescapable.

\section{References}

AEF-ISOBUS guidelines. 2015. Agricultural Industry Electronics Foundation. http://www.aef-

online.org/fileadmin/MEDIA/downloa ds/2015/AEF_handfan_EN_1015_lr.pdf.

AGCO. 2016. Fendt X-Concept. Available at: http://www.fendt.com/int/7710.asp.

Amazone. 2009. UX eSpray trailed sprayer. Available at: http://info.amazone.de/ DisplayInfo.aspx?id=14005.

Angrisani, G., Canelli, M., Roselli, C. and Sasso, M. 2015. Integration between electric vehicle charging and microcogeneration system. Energy Conversion Management; 98:115-26.

Aumer, W., Lindner, M., Geibler, M., Herlitzius, T. and Bernhardt G. 2008. Conceptual comparison of electrical and hydrostatic propulsion in combine harvesters. Landtechnik; 63(2):88-9.

Barthel, J., Gorges, D., Bell, M. and Munch, P. 2014. Energy management for hybrid electric tractors combining load point shifting, regeneration and boost. In: Vehicle Power \& Propulsion Conf., Coimbra, Portugal.

Barucki, T. 2001. Layout and optimizing of electric drive for tractors. Landtechnik; 56(2):436-40.

Bernhard, B. and Kutzbach, H. 2002. Serial hybrid electric drive train for a combine harvester. Agric. Eng. 
Budapest, Hungary; Paper no. 02-PM023.

Bernhard, B. and Schlotter, V. 2003. Electric drives for combine harvesters. In: Proc. Int. Conf. on crop harvesting and processing. Louisville, Kentucky, USA.

Bernhard, B. and Schreiber, V. 2005. Experimental comparison of ground drives for combine harvesters. Landtechnik; 60(2):82-3.

Biziorek, S. 2012. Round baler with electrically driven roller. EP-2 382 858 B1.

Boldea, I., Tutelea, L., Parsa, L. and Dorrell, D. 2014. Automotive electric propulsion systems with reduced or no permanent magnets: an overview. IEEE Trans.; 61(10):696-711.

Buning, E., 2010. Electric drives in agricultural machinery - approach from the tractor side, In: $21^{\text {st }}$ Annu. Meeting, Club of Bologna. http://www.

clubofbologna.org/ew/documents/knr_ buning.pdf.

Chan, C. 2007. The state of the art of electric, hybrid, and fuel cell vehicles. Proc.IEEE; vol. 95(4):704-718.

Chen, Z., Mi, C., Xiong, R., Xu, J. and You, C. 2014. Energy management of a power-split plug-in hybrid electric vehicle based on genetic algorithm and quadratic programming. J. Power Sources; 248:416-426.

Dorrell, D. 2012. Are wound-rotor synchronous motors suitable for use in high efficiency torque-dense automotive drives? Proc. IEEE IECON, $38^{\text {th }}$ Annu. Conf.; p. 4880 4885.

Ebbesen, S., Elbert, P. and Guzzella, L. 2013. Engine downsizing and electric hybridization under consideration of cost and drivability. Oil Gas Science and Technology - Review; 68(1):109116.

Ehsani, M., Gao, Y. and Miller, J. 2007. Hybrids electric vehicles: architecture and motor drives. Proc. IEEE; 95(4):719-728.

Emadi, A., Lee, Y. and Rajashekara, K. 2008. Power electronics and motor drives in electric, hybrid electric and plug-in hybrid electric vehicles. IEEE Trans.; 55(6):2237-2245.

Favache, S. 2002. Harvesting machine with electrically driven material conveyor and/or material processing device. US Patent 0056262 A1.

Florentsev, S., Izosinov, D., Makorov, L., Baida, S. and Belousov, A. 2010. Complete traction electric equipment sets of electro-mechanical drive trains for tractors. IEEE \& SIBIRCON. Irkutsk, Russia.

Fuel Cells Bulletin. 2009. Hydrogen-powered tractor unveiled at Paris show. Fuel Cells Bull., (February).

Fuel Cells Bulletin. 2012. New Holland NH2 fuel cell powered tractor. Fuel Cells Bull.: 3, (January).

Gallmeier, M. 2009. Comparative assessment of hydraulic and electric module drives for applicability in agricultural working machines. Ph. D. Dissertation, Technische Universität Munchen.

Gallmeier, M. and Auernhammer, H. 2004. Towards electric drive lines in mobile equipment. Agric. Eng., Leuven, Belgium; 2004010.

Götz, M., Grad, K. and Weinmann, O. 2012. Electrification of agricultural machinery. ATZ off-highway; 2:1120.

Herlitzius, T. 2011. Rigitrac EWD 120-Diesel electric. Tecnische Universität Dresden. Available at: <http://tudresden.de/die_tu_dresden/fakultaeten /fakultaet 
maschinenwesen/ifvlv/landmaschinen/ forschung/files/flyer_rigitrac.pdf>

Hofman, T., Steinbuch, M., Druten, R. and Serrarens, A. 2009. Design of CVTbased hybrid passenger cars. IEEE Trans. - Vehicle Tech.; 58(2): 572587.

Hoy, R., Rohrer, R., Liska, A., Luck, J., Isom, L. and Keshwani, D. 2014. Agricultural industry advanced vehicle technology: benchmark study for reduction in petroleum use. Idaho National Laboratory.

Karner, J., Heinrich, P. and Kogler, F. 2012. "Electric Drives in Agricultural Machinery", Int. Conf. Agric. Eng.,CIGR, Available at: http://cigr. ageng2012.org/comunicacionesonline/ htdocs/principal.php?seccion=index_p osters.

Karner, J., Prankl, H. and Kogler, F. 2012. Electric drives in agricultural machinery. CIGR-Agric. Eng., Valencia, Spain.

Katrasnik, T. 2007. Hybridization of powertrain and downsizing of IC engine - a way to reduce fuel consumption and pollutant emissions - Part I. Energy Conversion Manag.; 48:1411-23.

Kim, H., Park, Y., Hong, J. and Kang, K. 2014. All-graphene battery: bridging the gap between supercapacitors and lithium ion batteries. Scientific Report; 4:5278.

Kucinskis, G., Bajars, G. and Kleperis, J. 2013. Graphene in lithium ion battery cathode materials: a review. J. Power Sources; 240:66-79.

Küpfer, E. and Leu, A. 2013. Electric servodrives prove themselves in outdoor use. CAN Newsletter; 4:38-9.

Marlin, O. 2011. Coming Soon: Tractor Electrification, Resour. Eng. and Tech. for Sustain. World, Special issue, September/October, 2011, pp.16-17.

Michael, R. 2012. Tractors Final Emissions, Techs \& Specs - The Western Producer Publications, pp.1-13.

Mohsenimanesh, A., Laguë, C., Luo, C. and Habash, R. 2014. Electric multi-motor drives with improved induction machine for agricultural wide-span implement carrier (WSIC). ASABE \& CSBE/SCGABAnnu. Int. Meeting. Montréal, Québec Canada. Paper no. 141893614.

Moreda, G. P., Munoz-Garcia, M. A. and Barreiro, P. 2016. High voltage electrification of tractor and agricultural machinery - A review. Energy Conversion and Manag.; 115:117-131.

Mousazadeh, H., Keyhani, A., Javadi, A., Mobli, H., Abrinia, K. and Sharifi, A. 2010. Evaluation of alternative battery technologies for a solar assist plug-in hybrid electric tractor. Transport Res., Part D; 15: 507-512.

Nemry, F., Leduc, G. and Muñoz, A. 2009. Plug-in hybrid and battery electric vehicles: state of the research and development and comparative analysis of energy and cost efficiency. JRC tech notes. European Commission JRC-IPTS.

Neunaber, M. 2011. Four motors $=25 \%$ less fuel use. Profi.;8:24-27

Osinenko, P., Geisler, M. and Herlitzius, T. 2015. A method of optimal traction control for farm tractors with feedback of drive torque. Biosystems Eng.; 129: 20-33.

Pessina, D., Facchinetti, D. and Gemelli, D. 2009. Macchine Agricole luglio:4451.

Pohlandt, C. and Geimer, M. 2015. Variable DC-link voltage powertrain for electrified mobile work machines. In: International conference on electr. 
syst. for aircraft, railway, ship propulsion and road vehicles (ESARS), Aachen; pp. 1-5.

Ponomarev, P., Minav, T., Aman, R. and Luostarinen, L. 2015. Integrated electro-hydraulic machine with selfcooling possibilities for non-road mobile machinery. J. Mech. Eng.; 61(3):207-213.

Puhovoy, A. 2011. Agricultural tractor with pure electromechanical drivetrain. SAE-Int. J. Commercial Vehicles; 4(1):275-85.

Rahe, F., Wessels, T., Weinmann, O. and Götz, M. 2013. Field trials with EDX eSeed and ZF Terrat. In: $4^{\text {th }}$ Colloquium on Elektrische Antriebe in der landtechnik. Wieselburg, Austria.

Rauch, N. 2010. Experiences and visions of an implement manufacturer. Key note report, In: $21^{\text {st }}$ annu. meeting of the Club of Bologna, Bologna.

Rossi, C., Pontara, D. and Casadei, D. 2014. E-CVT power split transmission for off-road hybrid electric vehicles. In: Vehicle power \& propulsion conf. (VPPC), Coimbra, Portugal.

Rydberg, K. 2009. Energy efficient hydraulic hybrid drives. The $11^{\text {th }}$ Scandinavian Int. Conf. on fluid power, Linköping, Sweden. pp. 1-14.

Shabbir, W. and Evangelou, S. 2014. Efficiency analysis of a continuously variable transmission with linear control for a series hybrid electric vehicle. In: $19^{\text {th }}$ World cong. The international federation of automatic control. Cape Town, South Africa.

Sheidler, A., Musser, J., and Finamore, P. 2009. Vehicle with electric hybrid powering of external loads and engine off-capability. US Patent 0294191 A1.

Singh, B., Wanner, K. and Vilar, Z. 2014. Novel and ruggedized power electronics for off-highway vehicles. IEEE Electrification Mag. pp.31-41.

Somà, A. 2013. Effects of driveline hybridization on fuel economy and dynamic performance of hybrid telescopic heavy vehicles. Proc. of technologies for high efficiency \& fuel economy. Rosemont (Ill USA): SAE.

Somà, A., Boso, N. and Merlo, A. 2015. Electrohydraulic hybrid lifting vehicle. US Patent 8978800 B2.

Somà, A., Bruzzese, F. and Viglietti, E. 2015. Hybridization factor and performances of hybrid electric telescopic heavy vehicles. In: $10^{\text {th }}$ Int. conf. on ecol. vehicles renewable energies (EVER). Monte Carlo, Monaco; 9p.

Stoss, K., Sobotzik, J., Shi, B. and Kreis, E. 2013. Tractor Power for Implement Operation Mechanical, Hydraulic, and Electrical: an Overview, In: Agric. Equip. Tech. Conf., Am. Soc. Agric. and Biol. Eng.

Tritschler, P., Bacha, S., Rullière, E. and Husson, G. 2010. Energy management strategies for an embedded fuel cell system on agricultural vehicles. In: $19^{\text {th }}$ Int. conf. on electr. machines, ICEM-IEEE; p. 2.

UNECE. 2013. Uniform provisions concerning the approval of vehicles with regard to specific requirements for the electric power train. Agreement 12, Addendum 99: Regulation No. 100 (Rev. 2); 82p.

\section{How to cite this article:}

Dipak S. Khatawkar, P. Shaji James and Dhalin, D. 2019. Modern Trends in Farm MachineryElectric Drives: A Review. Int.J.Curr.Microbiol.App.Sci. 8(01): 83-98. doi: https://doi.org/10.20546/ijcmas.2019.801.011 